\title{
Chapter 5 \\ An Environmental Perspective on Energy Development in Indonesia
}

\author{
Fitrian Ardiansyah, Neil Gunningham and Peter Drahos
}

\begin{abstract}
Indonesia faces an energy trilemma on the energy security, climate change goals and energy poverty fronts. Policies that focus exclusively on one prong of the trilemma may lead to unacceptable consequences in the others. Conceiving the predicament as a trilemma will encourage a more unified approach to its problem solving. Successful management will require a search for policy complementarities - the likeliest source of which may be the renewable energy sector-that allow the country to move forward on all three fronts. A reform of its bureaucracy to address implementation gaps in its energy policy will also be needed. The reduction in transaction costs associated with the implementation of Indonesia's energy policy could be used as a broad criterion when considering these necessary changes.
\end{abstract}

\author{
F. Ardiansyah ( $\bowtie)$ \\ WEH Stanner Room \#1.38, Crawford School of Economics and Government, \\ The Australian National University (ANU), 132 Lennox Cross, Canberra, \\ ACT 0200, Australia \\ e-mail: fitrian.ardiansyah@anu.edu.au \\ http://fitrianardiansyah.wordpress.com \\ N. Gunningham \\ National Research Centre for Occupational Health and Safety Regulation, \\ RegNet, Research School of Pacific and Asian Studies, \\ The Australian National University (ANU), Canberra, \\ ACT 0200, Australia \\ e-mail: neil.gunningham@anu.edu.au \\ http://www.anu.edu.au/fellows/ngunningham/ \\ P. Drahos \\ Centre for Governance of Knowledge and Development, \\ RegNet, Research School of Pacific and Asian Studies, \\ The Australian National University (ANU), \\ Canberra, ACT 0200, Australia \\ e-mail: peter.drahos@anu.edu.au \\ http://www.anu.edu.au/fellows/pdrahos/
}


Keywords Energy security - Energy poverty - Renewable energy - Biofuels • Climate change $\cdot$ Environmental impacts $\cdot$ Deforestation

\subsection{Introduction}

Indonesia $^{1}$ (Fig. 5.1) is faced with a policy trilemma consisting of three prongs: energy security, climate change mitigation and energy poverty reduction. Simply put, achieving one of these policy goals will entail compromise on the achievements of at least one of the others. For example, Indonesia's most probable path to energy security is to heavily rely on its coal and gas reserves. However, its President, Susilo Bambang Yudhoyono, has made commitments under the Copenhagen Accord to reduce greenhouse gas (GHG) emissions by $26 \%$ by 2020 and to increase the use of renewable energy so that it accounts for $25 \%$ of total energy production by 2025 . Any energy security pathway that is based on fossil fuels will make achieving such climate mitigation targets difficult. Indeed, increased emissions from fossil fuel combustion are projected to increase GHG emissions in Indonesia fourfold by $2030 .^{2}$

Critics might argue that the above trilemma is overstated, given that it possible to identify policy complementarities as well as conflicts. For example, Indonesia has more geothermal energy potential than any other country$27,000 \mathrm{MW}$ of potential geothermal energy reserves ${ }^{3}$ - that if exploited properly would go a long way to help Indonesia meet its energy security and climate mitigation goals. However, such development, while desirable, is fraught with hurdles. In a politically frictionless world, Indonesia might have been able to transit seamlessly to geothermal energy; in reality though, Indonesia has to make this transition in keeping with present institutional structures and political networks under which the price of fossil fuel is not only heavily subsidised but also centrally set. That the state electricity generator, Perusahaan Listrik Negara (PLN) ${ }^{4}$ which purchases all power, has set the price of energy from renewable sources such as geothermal at a rate so high as to make its production untenable does not help either. The commercialisation of geothermal energy, in some

\footnotetext{
1 The Government of Indonesia, “The Geography of Indonesia”, at: http://www.indonesia.go.id/ en/indonesia-glance/geography-indonesia.html (29 June 2011).

${ }^{2}$ Fiscal Policy Office (Ministry of Finance); World Bank, "Phase 1 Assessment of EmissionsKey Findings", in: Low Carbon Development Options for Indonesia, at: http://www.esmap.org/ esmap/sites/esmap.org/files/factsheet04.pdf (16 March 2011).

3 See Allard, Tom, "Indonesia Goes to Ground for Energy", in: Sydney Morning Herald (1 May 2010), at: http://www.smh.com.au/environment/energy-smart/indonesia-goes-to-ground-forenergy-20100430-tzbv.html (16 March 2011).

4 For PLN's full profile, see "Company Profile", at: http://www.pln.co.id/eng/?p=102 (12 August 2011).
} 


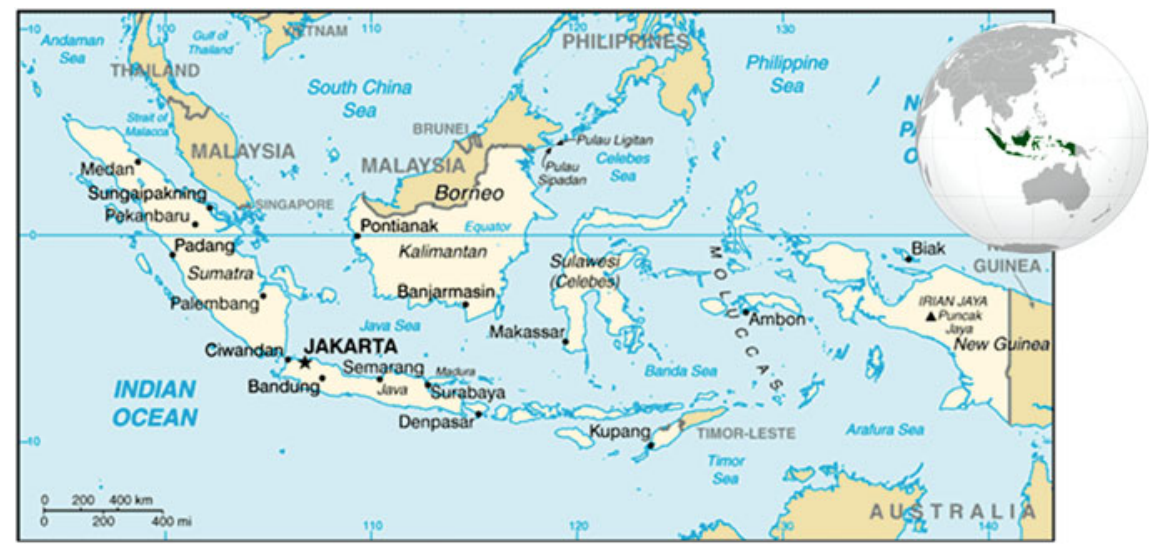

Fig. 5.1 Map of Indonesia. Source CIA 2011 (CIA, "East and Southeast Asia: Indonesia", in: The World Factbook (14 June 2011), at: https://www.cia.gov/library/publications/the-worldfactbook/maps/maptemplate_id.html (29 June 2011)

circumstances, also involves a direct conflict with the long-established, well-organised and powerful forestry industry, as an estimated $60 \%$ of geothermal energy sources are located in forest areas that are also subject to the recently enacted laws on pristine forests, including stricter conditions under which licences are to be issued (Girianna 2009, p. 2). Compounding the problem is the fact that nearly half of these resources belong to local governments while the rest is in the hands of state-owned companies. ${ }^{5}$

One message this chapter drives home is that the renewable energy targets that Indonesia is setting for itself risk becoming an unattainable wish list if they are not accompanied by a mix of regulatory strategies that are sensitive to the feasibility constraints being imposed by Indonesia's institutions and politics. For example, the fuel subsidy that was used during the Suharto regime to ensure the availability of cheap energy has turned into a huge fiscal burden for the state, amounting to nearly $21 \%$ of total government expenditure in 2005, that has hitherto continued to rise (Resosudarmo et al. 2010, p. 2). Addressing such feasibility constraints and others like it will require Indonesian policymakers to chart regulatory and governance courses that accompany the political goals and promises being made by the current Indonesian President. Then again, as is generally the case, it is easier to provide a thick description of problems and suggest general solutions, such as increasing investments in renewable energy, than it is to show how one might arrive at these solutions in a world where national political networks have to devise and execute the 'how to' prescriptions as well as bear the resulting costs.

5 "Potret Keadaan Hutan Indonesia Periode 2000-2009" (The Picture of Indonesia's Forests 2000-2009), in: FWI (Forest Watch Indonesia) (27 July 2011), at: http://fwi.or.id/?p=306 (31 August 2011). 
The rest of the chapter sets out the tensions and trade-offs that characterise the prongs of Indonesia's trilemma. Climate change, as will be elaborated later in this chapter, is a proxy for a set of nested environmental public good problems that are linked in various ways to available energy options in Indonesia. The chapter will explore these options, review both the obstacles and opportunities for the development of renewable, clean and sustainable energy, and assess whether these can provide effective solutions to Indonesia's energy challenge, particularly in terms of resolving its energy trilemma. Prior to this, however, the chapter will provide a profile of energy development in the country and its associated environmental impacts. This discussion seeks to identify a balanced solution that addresses both environmental protection and economic development when it comes to securing current and future energy for the country. The chapter will conclude by summarising its findings and discussing key possible steps towards the resolution of the energy trilemma. The final section suggests some areas where Indonesia needs to develop a 'how to' regulatory strategy in order to achieve the goals it has set for itself on energy diversification and climate change mitigation. In particular, the authors advocate the development of strategies that lower the transaction costs of Indonesia's decentralised governance arrangements around energy investment and regulation.

The analysis presented in this chapter was supported by literature and data reviews as well as semistructured interviews and focus group discussions with key stakeholders. The latter included officials from state agencies, non-state actors (including non-governmental organisations), international organisations, and Indonesia specialists situated both in Indonesia and other countries. Overall, 22 interviews were conducted, ${ }^{6}$ with a focus on contemporary policies, politics and the institutional construction of the energy sector, thereby providing a basis for the critical assessment of the environmental aspect of energy development in Indonesia.

\subsection{Energy Mix: Context and Challenges}

Indonesia is the largest energy producer and consumer in Southeast Asia. Based on the levels of energy elasticity and intensity, Indonesia falls into the category of 'consumptive' or 'close to wasteful'. For example, the energy elasticity ${ }^{7}$ figures for Indonesia (1.04-1.35) for the period between 1985 and 2000 (Koalisi Energi 2005 , p. 3) are relatively high when compared with corresponding figures of

\footnotetext{
${ }^{6}$ WWF-Indonesia commenced a climate and energy programme in 2003 whose work, until the writing of this chapter in 2011, has increasingly gained recognition both nationally and internationally. The first author served as a director in this programme between 2007 and 2010. Between late 2010 and early 2011, he served as advisor to WWF-Indonesia and was involved in the energy governance research of Indonesia that was led by Professors Neil Gunningham and Peter Drahos of the ANU.

${ }^{7}$ Energy elasticity is defined as the percentage change in energy consumption to achieve $1 \%$ change in national GDP.
} 
developed countries $(0.55-0.65)$ for the same period. Similarly, the energy intensity of Indonesia (index, 500) is five times that of Japan (index, 100) and higher than that of North America (index, 300), Organisation for Economic Cooperation and Development (OECD) countries (index, 200), and even Thailand (index, 350) (Koalisi Energi 2005, p. 3). Historical data shows that demand increases in line with, if not faster than, economic development and population growth (ESDM 2010, pp. 2-3). From 1990 to 2006, for instance, Indonesia's compound annual growth rate of total final energy consumption (excluding biomass) was about $5.5 \%$, or an increase from 245 millions of barrels of oil equivalent (mmboe) to $577 \mathrm{mmboe}^{8}$ According to the Green Policy paper released by its finance ministry, total energy demand is growing by around $7 \%$ annually, as the transport and industrial sectors grow and as households become more affluent (Ministry of Finance 2009, p. 5).

Indonesia appears to be struggling to keep up with its energy demands, and its dependency on oil imports to fuel its economy and cope with its problems of energy security seem no longer economically viable. Soaring average global oil prices, reaching US\$113.61 per barrel in June 2011, ${ }^{9}$ have placed considerable strains on the Indonesian economy. The state budget is burdened by heavy oil and electricity subsidies ${ }^{10}$ — subsidy costs to the government were estimated at US $\$ 9.78$ billion in $2010^{11}$ and US\$3.68 billion as of March 2011. ${ }^{12}$ The high price of oil on the global market has also caused a spike in electricity generation costs upstream. The transport sector, much like the energy sector, is a large consumer of fossil fuels too-consumption increased from 6 million tonnes of oil equivalent (mtoe) in 1980 to 25 mtoe

\footnotetext{
8 Ardiansyah, Fitrian; Wardhini, Indra Sari; Suhud, Muhammad, "Road to Copenhagen: Helping Indonesia Advance as its Emissions Decrease", in: The Jakarta Post (27 October 2009), at: http:/l www.thejakartapost.com/news/2009/10/27/road-copenhagen-helping-indonesia-advance-its-emissionsdecrease.html (16 January 2012).

9 "World Crude Oil Prices", in: US-EIA (U.S. Energy Information Administration) (17 June 2011), at: http://www.eia.gov/dnav/pet/pet_pri_wco_k_w.htm (28 June 2011).

${ }^{10}$ Under the Suharto regime, which was anxious to maintain social stability, there was an emphasis not only on food but also energy security. As in a number of other developing countries, the central government subsidised the price of a variety of energy products, including low-octane gasoline, kerosene, diesel, liquefied petroleum gas (LPG) and electricity, with the aim of ensuring that energy was cheap and available (Agustina et al. 2008, p. 12). As long as the price of oil was low and the value of the rupiah relatively high, the subsidies remained modest. However, the Asian financial crisis of 1997 resulted in a substantial fall in the value of the rupiah even as the price of crude oil rose substantially in the early 2000s. Fuel subsidies increased markedly from 1998 to 2000 following the sharp depreciation of the rupiah relative to the US dollar, peaking in 2000 and accounting for 28.6 per cent of total spending (Agustina et al. 2008, p. 12). In 2008, fuel and electricity subsidies together reached US $\$ 20.5$ billion (Agustina et al. 2008, p. 3).

11 Suharmoko, Aditya. "Govt Likely to Increase Fuel Subsidy: Minister", in: The Jakarta Post (7 August 2010), at: http://www.thejakartapost.com/news/2010/07/08/govt-likely-increase-fuelsubsidy-minister.html (16 March 2011).

12 Kertiyasa, Martin Bagya, "Maret, Subsidi Energi Rp32,3 Trilyun" (March, Energy Subsidy Rp32.3 Trillion), in: Okezone (14 April 2011), at: http://economy.okezone.com/read/2011/04/14/ 20/445920/ (15 April 2011).
} 
in 2005 or $48 \%$ of the national fuel consumption (Timilsina and Shrestha 2009, p. 4528). The demand for energy from this sector is projected to increase rapidly, ${ }^{13}$ and this growing demand coupled with the high cost of petroleum has prompted Indonesia to urgently seek fossil fuel substitutes, including vegetable oils.

A large amount of this demand has been met by fossil fuels, mainly oil. Since 2004 , the country is a net importer of both crude oil and refined products ( $\mathrm{Sa}^{\prime} \mathrm{ad}$ 2009 , p. 4391). In 2004, for instance, production averaged 1,100 tbd while consumption hit 1,200 tbd (Sa'ad 2009, p. 4392). With a production capacity of 0.5 billion barrels per year and increasingly limited oil reserves, it is estimated that Indonesia's remaining 10 billion barrels of oil reserves will be exhausted in less than 20 years (Koalisi Energi 2005, p. 3). Should no new reserves be found, given its increasing demands for energy and a 'business as usual' approach, Indonesia is projected to become a significant oil-importing country in less than two decades.

While its oil reserves may be diminished, the country remains extremely rich when it comes to energy resources-Indonesia is widely known to have bountiful natural resources, including the renewable forms of energy such as run-of-the-river hydropower, geothermal, solar and biomass. It is the second largest thermal coal exporter after Australia $^{14}$ and remains a major liquefied natural gas (LNG) exporter (IEA 2008, p. 109). It has the world's tenth largest reserves of natural gas accounting for some $40 \%$ of the world's geothermal reserves (Leitmann et al. 2009 , p. 67), which albeit underutilised might potentially meet some $40 \%$ of its electricity demands (Leitmann et al. 2009, p. 67). ${ }^{15}$ Biofuels are being explored as well, including those sourced from palm oil, Jathropha curcas and castor oil.

The development of renewable sources over the past several years has, however, progressed very slowly. According to a 2009 World Bank report, for example, these resources were still largely unexploited and underdeveloped despite their high potential as clean domestic energy sources (World Bank 2009, p. 2). Domestic power generation has remained a particular challenge, with the majority of energy sources for such generation currently being conventional thermal sources that include fossil fuels, such as oil, coal and natural gas-less than $20 \%$ of power generation is accounted for by hydroelectric, geothermal and other renewable sources. ${ }^{16}$ Compounding matters further, Indonesia has

\footnotetext{
13 "Indonesia Overtakes Thailand in Car Sales", in: The Independent (1 August 2010), at: http:// www.independent.co.uk/life-style/motoring/indonesia-overtakes-thailand-in-car-sales-2040988. html (16 March 2011).

14 “Indonesia May Ban Low Quality Exports from 2014”, in: Bloomberg (24 January 2011), at: http://www.steelguru.com/raw_material_news/Indonesia_may_ban_low_quality_coal_exports_ from_2014/187736.html (16 March 2011).

15 President Susilo Bambang Yudhoyono has announced plans for Indonesia to become the world's leading geothermal nation, with 44 plants to be built by 2014 and its 4,000 MW capacity rising to 9,000 MW by 2025; see Allard, Tom, "Indonesia Goes to Ground for Energy", in: Sydney Morning Herald (1 May 2010), at: http://www.smh.com.au/environment/energy-smart/ indonesia-goes-to-ground-for-energy-20100430-tzbv.html (16 March 2011).

16 "Share of Total Primary Energy Supply in 2008: Indonesia", in: IEA (International Energy Agency) (2010), at: http://www.iea.org/stats/pdf_graphs/IDTPESPI.pdf (16 March 2011).
} 
complicated its energy security over the last 20 years by selling a substantial part of its oil and coal (and to some extent, gas) to a number of energy-hungry countries under long-term contracts. ${ }^{17}$ Steps are being taken to put this right-Indonesia's energy policy has in recent times seen a sea change, as the country's political leaders have come to appreciate the serious difficulties that are to be faced in securing and providing basic energy to its citizens. For instance, Indonesia is a substantial exporter of LNG, ranking third after Qatar and Malaysia, and a substantial percentage of its energy resources are exported. In 2004, $70 \%$ of Indonesia's LNG exports went to Japan, $20 \%$ to South Korea and $10 \%$ to Taiwan. ${ }^{18}$ However, new deals between Japanese companies and Indonesia's PERTAMINA (Perusahaan Tambang dan Minyak Negara) ${ }^{19}$ over LNG are for considerably less volumes than previously considered, in line with a general decrease in Indonesia's LNG exports following the realisation of decreasing supply amid increasing domestic demand. ${ }^{20}$

Indonesia has plans to promote coal and biofuels for addressing energy security, but these may create additional problems in terms of its climate change mitigation targets. The use of coal entails emission costs just as aggressive biofuel development may contribute to GHG emissions. According to a recent report, although presently more than $90 \%$ of Indonesia's GHG emissions are from the forestry and land-use sectors, any rapid increase in emissions from the energy sector in the future-should more coal power plants be built and biofuel crops replace the remaining forests and peatlands-would make Indonesia an important contributor to GHG emissions (USAID 2008, p. 16). Correspondingly, reports also project raised carbon dioxide $\left(\mathrm{CO}_{2}\right)$ emissions by 2030 (DNPI 2010, p. 25). Such increase in emissions will exacerbate climate change to which Indonesia, an archipelagic nation, is particularly vulnerable (Ministry of Environment 2009, p. 12). Indeed, climate change is credited with creating an increasing threat to economic activities within the country, including damage to assets from extreme weather, loss of agricultural outputs due to droughts, flooding, transboundary haze and unseasonal

17 As to China's resource relationship with Indonesia, see Chaney, Joseph; Wee, Sui-Le, "Indonesia's Resources Appeal Grows on China", in: Reuters (17 February 2010), at: http:// www.reuters.com/article/2010/02/17/us-dealtalk-indonesia-resources-idUSTRE61G2K220100217 (16 March 2011); for a general, but somewhat dated energy profile, see "Indonesia Energy", at: http:// wn.com/s/indonesiaenergy_old1/ 16 March 2011.

18 "Indonesia", in; Indonesia Energy Info (July 2004), at: http://wn.com/s/ indonesiaenergy_old1/ (16 March 2011); Alfian; Fox, David, "Indonesia LNG Exports to Fall to 362 Cargoes This Year", in: Reuters (18 January 2011), at: http://www.reuters.com/article/ idUSL3E7CIOUK20110118 (16 March 2011).

19 PERTAMINA is Indonesia's state-owned oil and gas company. For the company's full profile, see "Company Profile", at: http://www.pertamina.com/index.php/home/read/company_profile (12 August 2011).

20 "Raft of New Deals as Japan and Indonesia Agree LNG Terms", in: Business Monitor International (March 2008), at: http://www.oilandgasinsight.com/file/63096/raft-of-new-dealsas-japan-and-indonesia-agree-lng-terms.html (16 March 2011). 
weather, and disruption to business from infrastructure damage or disruption (Ministry of Environment 2009, p. 12).

Last but not the least, the policies that Indonesia chooses vis-à-vis climate change mitigation and energy security are bound to have a profound impact on the final component of the energy trilemma, that is, energy poverty. Fuel subsidies, as is the case in many developing countries, play a pivotal role in Indonesia's politics. As a G20 member, Indonesia has agreed to phase out fuel subsidies, a brave promise given that some $50 \%$ of its 225 million inhabitants exist on less than US $\$ 2$ a day. Some 80 million people in Indonesia, primarily those in rural areas, still lack access to electricity ${ }^{21}$ and many others experience energy insecurity in the form of frequent blackouts and brownouts. For those without electricity and who subsist on less than US $\$ 2$ a day, traditional biomass (such as the three-stone fire) is the principal source of energy; it is known to cause several problems, including premature death from household air pollution-more poor people die prematurely from this than do from malaria or tuberculosis (OECD/IEA 2010, p. 13). Certainly, access to electricity for poor people is an obvious priority as is access to clean cooking fuel.

Fuel subsidies do a poor job of benefiting the rural poor, tending to favour urban populations through the provision of cheap electricity (Resosudarmo et al. 2010, pp. 14-15). Nonetheless, while it is true that the rich benefit disproportionately from the subsidy (Pallone 2009, p. 5), it is also true that the poor receive some immediate benefit as well. Although removing fuel subsidies would send the correct price signals to Indonesia's energy markets, it would in the short term lessen access to energy for poor people and deepen the country's energy poverty. Driving the poor into further energy poverty may also drive out hope for some, a dangerous path for any government to tread. For this reason, simply sweeping the subsidy away would be full of political risk.

There is uncertainty as to whether the Indonesian political elite will act quickly to dispose off fuel subsidies. As one official the authors interviewed pointed out: "for a developing country, the subsidy is not just about economic policy; it's very dependent on political policy. Our proposal to make an adjustment to the tariff is restricted by Parliament, so we can't do it. It's not easy! So you shouldn't push developing countries too far". This was reiterated by another interviewee from the Ministry of Finance who pointed out that while the ministry did have plans to phase out subsidies, one had "to remember, if we remove the energy subsidy, we get higher inflation and higher poverty ...". There are no obvious easy resolutions to such problems, and it is, therefore, not surprising that Indonesian policymakers are inclined to talk in vague terms about incremental changes to be phased in at some future point in time comfortably beyond the current political cycle.

\footnotetext{
21 "Snapshot of Electrification throughout ASEAN", in: Asian Trends Monitoring (29 July 2010), at: http://www.asiantrendsmonitoring.com/2010/07/29/snapshot-of-electrification-throughout-asean (16 March 2011); Barbotte, Daphné, “Country Spotlight: Indonesia”, in: REEEP (5 September 2010), at: http://www.reep.org/index.php?id=443\&special=showHotTopic\&iHotId=861\&sQuiteName= news\&iQuiteId=436 (16 March 2011).
} 
Nevertheless, over time, one can expect the existing subsidies to be removed as their costs mount and more targeted ways are found to compensate poor people. Senior Indonesian bureaucrats are cognisant that subsidies are a problem that will have to be dealt with using long-term negotiations and not sweeping radical reform. There is not much else that can be said about this issue.

\subsection{Energy Development: Options, Impacts and Failings}

The pressures on energy security and the economy have prompted Indonesia to reconfigure its energy policy. With supplies of domestic oil dwindling, reliance on oil imports increasing, and energy demand and the need to combat energy poverty growing, Indonesia is looking, with increasing urgency, for additional conventional sources of power and alternative sources of energy. The cheapest short-term source of electricity for Indonesia is definitely coal-PLN has plans, with regard to electricity, to develop and promote coal-dominated power plants for Java and diesel-dominated plants for the outer islands. Options that can help Indonesia meet its demand for energy while ensuring that negative environmental impacts are avoided or reduced, are also being pursued. Indonesia's huge geothermal reserves if utilised correctly, would reduce its GHG emissions and help it gain carbon credits. Similarly, biofuel development, if undertaken responsibly for non-forested and non-peatland areas, would contribute positively to climate change mitigation and economic development.

\subsubsection{Coal}

Coal is central to Indonesia's energy mix and policies, both present and future, and emerges as an obvious choice in Indonesia's hunt for a suitable energy source - the country has a plentiful supply of the resource and coal-fired power stations use well-established technology that can be purchased relatively cheaply and assembled relatively quickly. These cost factors led, in 2006, to a government 'crash programme' that aimed to develop 10,000 MW from coal-fired plants that would be readied in the coming years, as stipulated in the Presidential Decree No. 71 of 2006 (Leitmann et al. 2009, p. 27). Under the programme, most plants were purchased cheaply from China and quickly assembled. While the programme did not provide long-term efficiency (interview data suggests that the plants were cheap because they were dirty and inefficient), the plants did bring about shortterm improvement in the operation of electricity grids. The programme was also attractive because it shifted energy generation away from the increasingly expensive and imported oil, which is slated for gradual phase-out.

Following the first programme, a second-phase crash programme, to be realised between 2009 and 2018, has also been introduced with the same projected increase 
in total intended capacity and at an estimated cost of US\$21.3 billion. ${ }^{22}$ While interviewees consistently suggested that even the second phase was primarily about coal, formal statements of Indonesian officials were to the contrary, suggesting that $60 \%$ of the new capacity would come from renewable resources, and that, in particular, approximately 5,000 MW or $48 \%$ would be from geothermal resources and $12 \%$ from hydro resources (Girianna 2009, p. 1).

Be that as it may, a dramatic surge in coal-fired plants will greatly increase GHG emissions and contribute to climate change. Notwithstanding current trends toward renewable sources for the energy and transport sectors, Indonesia's fossil fuel-based emissions are forecasted to triple by 2030 (World Bank 2009, p. 1). In the case of coal, per capita GHG emissions from fossil fuel consumption in Indonesia grew faster than in China and India even for the years between 1999 and 2004 (World Bank 2009, p. 2). With the government further planning to significantly increase the share of coal in the country's power generation fuel mix, GHG emissions are anticipated to grow faster than the economy (World Bank 2009, p. 2). An analysis from the Dewan Nasional Perubahan Iklim (DNPI; also known as National Council on Climate Change $[\mathrm{NCCC}])^{23}$ suggests that the country's emissions from the power sector are expected to grow sevenfold from 110 metric tonnes (tons) of $\mathrm{CO}_{2}$ equivalents $\left(\mathrm{MtCO}_{2} \mathrm{e}\right)$ in 2005 to $810 \mathrm{MtCO}_{2} \mathrm{e}$ in 2030 due to strong demand growth and an increasing dependence on coal (DNPI 2010, p. 25). DNPI projects that emissions from the power sector in 2030 will exceed those from the peat sector today (DNPI 2010, p. 25).

The ill effects of the use of coal as the predominant source of energy, however, do not end with increased emissions. Among others, coal may lead to significant environmental consequences, such as smog and acid rain, ${ }^{24}$ given the fact that gases are given off and ash particles released whenever coal is burnt. The sulphur in coal combines with oxygen to form sulphur dioxide, which can be a major source of air pollution if emitted in large enough quantities. ${ }^{25}$ When coupled with other industrial pollutants and motor vehicle emissions, the negative impact of coal on the health of urban populations can be serious, especially in terms of respiratory diseases (Leitmann et al. 2009, p. 65).

22 ESDM, "Second Phase of Electricity Crash Program and Development of Transmission and Distribution Networks", in: The Free Library (2009), at: http://www.thefreelibrary.com/ Second+phase+of+electricity+crash+program+and+development+of...-a0198850375 (16 March 2011).

${ }^{23}$ Dewan Nasional Perubahan Iklim (DNPI) or National Council on Climate Change (NCCC) is an institution set up by President Susilo Bambang Yudhoyono in July 2008 to coordinate climate change-related activities within Indonesia. The council is specifically tasked with the role of convening different stakeholders in Indonesia to create consensus around the opportunities and challenges related to climate change.

${ }^{24}$ Ardiansyah, Fitrian, "Indonesia's Energy Dilemma", in: The Jakarta Post (7 July 2010), at: http://www.thejakartapost.com/news/2010/07/06/climate-solutions-indonesia's-energy-dilemma. html (16 March 2011).

25 National Energy Foundation, "Background Information: How Does Burning Coal Affect the Environment”, at: http://www.coaleducation.org/lessons/twe/envi.htm (29 June 2011). 


\subsubsection{Palm Oil}

Indonesia has expanded its capacity for palm oil production and is now a leading producer in world terms. Like other vegetable oils, palm oil can be used as a fuel in vehicles and for electricity and heat generation. The Government of Indonesia, therefore, has promoted a plan to use oil palm-based biodiesel to reduce its dependency on fossil fuels by $10 \%$ in 2010 and $20 \%$ by 2025 (Ariati 2007, p. 12). ${ }^{26}$ With incentives, such as the allocation of US $\$ 1.15$ billion from the state budget for infrastructure related to biofuel development, tax incentives (30\% reductions on net profits) ${ }^{27}$ and interest rate subsidies (10\%) for smallholders, ${ }^{28}$ it is projected that numerous producers will take advantage of this favourable economic environment and rapidly expand palm oil production.

The development of biofuel crops, particularly palm oil, could further increase GHG emissions if palm oil plantations replace forests and peatlands. For example, in the Indonesian provinces of North Sumatra and Bengkulu, and in Peninsular Malaysia, 38, 35 and $27 \%$, respectively, of peat-swamp forest were converted to oil palm plantations by the early 2000s - this conversion led to the release of about 140 million tons of carbon from biomass above ground and 4.6 million tons of carbon from peat oxidation below ground. ${ }^{29}$ According to Koh and Wilcove's estimates (2008, p. 62), the forest area converted to oil palm plantations in Indonesia was 1.7 million ha between 1990 and $2005,{ }^{30}$ meaning that over $56 \%$ of oil palm expansion occurred at the expense of natural forest cover for the period. In terms of peatlands, Hooijer et al. (2006, p. 10) state that of the 10.3 million ha of land allocated to palm oil concessions, 2.8 million ha $(\sim 27 \%)$ are located on peatlands. According to the Badan Perencanaan Pembangunan Nasional (BAPPENAS; also known as National Development Planning Agency) (BAPPENAS 2009, p. 5), as of 2006, plantation licenses (i.e. predominantly for oil palm) on peatlands totalled 1.3 million ha.

The environmental problems that such conversions cause are exacerbated where drainage has been intensified to establish large-scale plantations. This results in very high annual emissions of up to a hundred tons of $\mathrm{CO}_{2}$ per ha, compared to only a few tons from recently logged areas (Hooijer et al. 2006, p. 10, 12, 15, 17-33). Considerably more carbon may be released into the atmosphere when fire is used to clear forests and peatlands and make way for oil palm plantations.

\footnotetext{
${ }^{26}$ See Presidential Instruction No. 5 of 2006 on National Energy Policy.

27 See Government Regulation No. 1 of 2007 on Income Tax Facilities to Investment Activities in Specific Industries and Particular Regions.

${ }^{28}$ See Ministry of Forestry Regulation No. 117/PMK.06/2006 on the Credit for the Development of Biofuel Energy and Plantation Revitalization.

29 Vaidyanathan, Gayathri, "Counting the Carbon Cost of Peatland Conversion", in: Nature (7 March 2011), at: http://www.nature.com/news/2011/110307/full/news.2011.139.html $>$ ?s= news_rss (29 June 2011).

30 In their analysis, Koh and Wilcove (2008, p. 62) assessed that between 1990 and 2005, oil palm cultivated areas in Indonesia increased by 3 million ha.
} 
Apart from forest and peat destruction for oil palm plantations causing GHG emissions, forest and peatland conversion to oil palm has led to the fragmentation of high conservation value forests (HCVF) and had other environmental (e.g. human-wildlife conflicts) and social impacts (e.g. land tenure conflicts) as well. There is therefore a need to ensure that using palm oil as a source for energy does not affect its availability as a food for the poor, who are least able to afford alternative sources (Colbran and Eide 2008, pp. 4-10), or deprive them of food that would otherwise be available if land were used differently. For example, the increasing involvement of conglomerates in the bioenergy business has led to fears of the marginalisation of small producers. There are also concerns about the insecurity of land ownership and tenure rights for rural communities that depend upon access to forest and agricultural resources and ecosystem services. Finally, Wilcove and Koh (2010, p. 999) argue convincingly that oil palm development and the destruction of forests pose the greatest immediate threat to biodiversity and forests in Southeast Asia.

Although contentious, there is no doubt that palm oil is increasingly being seen as a major renewable energy source. Where Indonesia is concerned, the demand for palm and other vegetable oils, in very large part, comes from the world market and not the domestic one. Certainly, it is the recent increase in global demand for palm oil as a biofuel source that has prompted such an expansion of the Indonesian palm oil industry. The European market, driven by the high cost of petroleum and political pressure from the climate change mitigation movement, is in particular importing ever-increasing amounts of palm oil, although as indicated below this trend may not continue so. The EU has set a target of $5.75 \%$ of energy from renewable sources by 2012, with biofuels playing a major role (Tindale 2009, p. 2). The US has pledged to increase the use of renewable fuels from 7.5 billion gal in 2012 to 35 billion gal in 2017 (EPRINC 2007, p. 4). Already, as of 2005, around 1.5 million tons of palm oil were used for this purpose in power stations throughout Europe (Reinhardt et al. 2007, p. 12).

Opportunities in Europe for Indonesian palm biodiesel producers, however, are likely to be closing (Sheil et al. 2009, p. 18). A 2008 directive issued by the European Parliament on biofuels and renewable energy sources has proposed three criteria for acceptable biofuels: (a) land with high carbon stocks should not be converted for biofuel production; (b) land with high biodiversity should not be converted for biofuel production; and (c) biofuels should achieve a minimum level (35\%) of GHG savings (Sheil et al. 2009, p. 18). The future for palm biodiesel is therefore likely to lie increasingly within Indonesia itself (as is also the case with Malaysia), and perhaps in other key consumer countries outside the EU, such as China and India. It is against this backdrop that the world's palm oil production is expected to nearly double by 2020 (Teoh 2002, p. 9). 


\subsubsection{Geothermal Energy}

Indonesia's geothermal resources have remained underutilised as pricing delays between the PLN and the government have marred its geothermal options. Although geothermal licences were granted in 2010, developers were unable to begin exploration because power-purchasing agreements with the PLN remained unsigned as it waited for the government's pricing approvals. ${ }^{31}$ These snags were apparently resolved on 1 January 2011 when the PLN introduced an $18 \%$ tariff hike ceiling, in line with the Energy and Mineral Resources Minister's Regulation No. 7 of 2010, as a temporary measure to resolve tariff discrepancies caused by the ministerial regulation in 2010. However, the cost of developing geothermal technology is still prohibitive, costing an estimated US\$800 million for a $333 \mathrm{MW}$ power plant, and completely beyond the capacity of the Indonesian government. Recognising the high risks of investment in geothermal resources, the World Bank announced a US $\$ 400$ million commitment from their Clean Technology Fund in early $20100^{32}$ The project is aimed at doubling Indonesia's geothermal energy capacity. ${ }^{33}$ In addition, the Lahendong Geothermal Plant is being financed by the World Bank, Asian Development Bank (ADB) $)^{34}$ and Japan International Cooperation Agency (JICA). ${ }^{35}$ JICA also undertook a study in March 2008 of the fiscal incentives that could accelerate Indonesia's geothermal capacity. The study

\footnotetext{
31 Exploration rights were granted as follows: the Jaboi field in Aceh was awarded to a consortium led by PT Bukaka Teknik Utama; the Sorik Marapi field in North Sumatera to a consortium of Tata Power and Origin Energy; the Muara Laboh field in West Sumatera and the Gunung Rajabasa field in Lampung to PT Supreme Energy; the Jailolo field in Halmahera to Star Energy; the Sokoria field in Flores Island to Bakrie Power; the Tangkuban Parahu field in West Java to PT Indonesia Power; the Cisolok field in West Java to PT Rekayasa Industri; the Tampomas field in West Java to PT Wijaya Karya; and the Ungaran field in Central Java to PT Golden Spike Energy Indonesia; see Alfian, "Indonesia Geothermal Program Hung Up on PLN Pricing Delay", in: The Jakarta Post (22 October 2010), at: http://www.thejakartapost.com/news/ 2010/10/22/indonesia-geothermal-program-hung-pln-pricing-delay.html (16 March 2011).

32 "Follow the Money: \$400 Million Indonesian Commitment Has Players Scurrying", in: Geothermal Digest (29 March 2010), at: http://geothermaldigest.net/blog/2010/03/29/follow-themoney-400-million-indonesia-commitment-has-players-scurrying/ (16 March 2011).

33 Padden, Brian, “World Bank Invests \$400 Million in Indonesian Geothermal Energy”, in: Voice of America (23 March 2010), at: http://www.voanews.com/english/news/World-BankInvests-400-Million-in-Indonesian-Geothermal-Energy-88906002.html (16 March 2011).

34 ADB financed the plant as one of 12 subprojects under its Renewable Energy Development Sector (REDS) Project, aiming to increase the electricity output from Lahendong geothermal plant to $158 \mathrm{GWh}$ (gigawatts hour) annually into PLN's Minhasa system of North Sulawesi; see World Bank, "ID-PCF-Indonesia Lahendong Geothermal Project" (25 August 2009), at: http:// web.worldbank.org/external/projects/main?pagePK=64283627\&piPK=64290415\&theSitePK= $40941 \&$ menuPK=228424\&Projectid=P096677 (16 March 2011).

35 JICA’s contribution of $¥ 5,866$ million (approximately US\$70 million), beginning in March 2004, involved building a new plant with a 20 MW capacity that is due for completion in 2012; see JICA, "Major Projects: Lahendong Geothermal Power Plant Project", in: JICA, at: http:// www.jica.go.jp/indonesia/english/activities/activity13.html (16 March 2011).
} 
considered the substitution of existing and planned diesel plants in the West Nusa Tenggara, East Nusa Tenggara, Maluku and North Maluku provinces. ${ }^{36,37}$

\subsubsection{Nuclear Energy}

Finally, Indonesia is researching nuclear power, with three separate proposals currently under consideration. ${ }^{38}$ Russian nuclear plant vendor, Rosatom, has proposed a small floating nuclear plant to supply Sulawesi. ${ }^{39}$ Another project, supported by the International Atomic Energy Agency (IAEA), involves a nuclearpowered desalinisation plant on Madura that will generate electricity for the JavaMadura-Bali electricity grid. ${ }^{40}$ The third plan is a revised proposal from the National Atomic Energy Agency (NAEA) for a major nuclear electricity generating station on the north coast of Central Java close to Mount Muria. ${ }^{41}$ In their third attempt to receive government backing since the early 1980s, the agency has proposed building the first of four 1,000 MW pressurised water reactors. The World Bank and the Ministry of Finance opposed the first attempt while the second was aborted due to the Asian financial crisis of $1997 .{ }^{42}$ Mitsubishi is expected to be one of the principal bidders should the Muria proposal go ahead. ${ }^{43}$

It is difficult to predict whether nuclear energy will materialise as a viable option for Indonesia in the near future, as government reports have often contradicted optimistic external prognostications. For example, in 2010, Energy and Mineral Resources Minister, Darwin Zahedy Saleh, when speaking about developing nuclear energy for electricity generation said, "[w]e will exploit other available energy sources first". ${ }^{44}$ There are strong antinuclear groups that distrust

\footnotetext{
36 "Pre-feasibility Study for Geothermal Power Development Projects in Scattered Islands of East Indonesia", in: Engineering and Consulting Firms Association, Japan (March 2008), at: http://www.ecfa.or.jp/japanese/act-pf_jka/H19/renkei/wjec_indonesia.pdf (16 March 2011).

37 Alfian; Desy Nurhayati, "PLN Needs to Subsidize Geothermal Power", in: The Jakarta Post (5 May 2010), at: http://www.thejakartapost.com/news/2010/05/05/pln-needs-subsidizegeothermal-power.html (16 March 2011).

38 "Indonesian Nuclear Power Proposals", in: Nautilus Institute for Security and Sustainability (7 February 2010), at: http://www.nautilus.org/initiatives/aus-indo/aust-ind-nuclear/ind-np/ contemporary/\#introduction (16 March 2011).

39 Ibid.

40 Ibid.

${ }^{41}$ Ibid.

42 Ibid.

43 "Mitsubishi Heavy Industries", in: Nautilus Institute for Security and Sustainability (19 January 2010), at: http://www.nautilus.org/initiatives/aus-indo/aust-ind-nuclear/ind-np/ muria/mitsubishi-heavy-industries (16 March 2011).

44 Nani Afrida, "Indonesia Will Not Develop Nuclear Power Anytime Soon: Minister", in: The Jakarta Post (2 May 2010), at: http://www.thejakartapost.com/news/2010/02/05/indonesia-willnot-develop-nuclear-power-anytime-soon-minister.html (16 March 2011).
} 
the Indonesian government and doubt its ability to manage nuclear technology (Amir 2009, p. 353). This is especially so now that the politics and risk management of the nuclear option have become even more costly and complex in the aftermath of the 2011 Fukushima nuclear power plant disaster in Japan. In any case, even in the most optimistic fast-tracking scenario, nuclear power is not expected to make a significant contribution to Indonesia's energy security before 2030 (Hawksworth 2006, p. 6).

\subsubsection{Indonesia's Position Vis-à-Vis the Trilemma}

These findings emphasise that although coal and biofuels may seem attractive as options that ease Indonesia's energy security troubles, the increase in emissions from coal-fired power plants and the conversion of forests and peatlands for biofuel production will further contribute to climate change to which Indonesia is vulnerable for a variety of reasons (Fredriksson et al. 2007, p. 1824). These fuels are also likely to create environmental and social problems, especially through their contribution to climate change, impact on the living standards and social conditions of poor people and, in the case of biofuels, biodiversity loss due to the destruction of forests. While Indonesia is not in control of its climate change destiny, given the public good nature of the problem, it arguably has vested interests in mitigation initiatives and in setting an example that other developing countries might follow.

Indonesia has made pledges and commitments on environmental and energy policy changes that have placed the country in the spotlight as a pioneer of climate change mitigation through the promotion of renewable energy. The energy challenge for Indonesia, however, is a particularly complex one, as it has to not only reconcile energy security and climate change mitigation concerns but also deal with the legitimate claims of its citizens to not be plunged into energy and economic poverty as a result of national policies. Yet, many of the policies that aim to achieve energy security may threaten to remove ordinary Indonesians from their land or may exacerbate climate change and lead to increased flooding, landslides, water- or vector-borne diseases, windstorms, forest fires, drought and high tides/ storm surges (Ministry of Environment 2009, p. 12). Moreover, forest and peatland conversion to oil palm has resulted in other environmental and social impacts, which, in the short term, may cause higher commodity prices that could negatively affect access to food for poor people (Colbran and Eide 2008, pp. 4-10). Managing such a trilemma is difficult because, in Indonesia's case, it is difficult to find policies that avoid energy poverty-fuel subsidies cannot simply be swept away; investing in geothermal sources produces obvious gains for energy security and the climate, but does not do much for the millions of poor that are not on the grid and require investments into off-grid solutions; investing in coal meanwhile will do more to help supply electricity to those in urban settings than those in rural areas. If nothing were to be done to supply electricity to the poor, their chances of finding ways to increase their income would be further reduced. 
The difficulty facing social, environmental and energy policymakers in Indonesia then is to determine how the country can develop its energy sector without causing additional negative climate, environmental and social impacts. Concerns regarding energy and social poverty are now so substantial and overt that they can no longer be ignored, either in social equity or political terms. A solution to this energy trilemma would be to develop energy that is reliable, affordable and sustainable. But, this is easy to say and indescribably difficult to achieve. At its heart, of course, is the sustainable development discourse and the implacable opposition of developing countries to sacrifice their future development and social and energy policy aspirations to an overweening goal of climate change mitigation.

Recognising the trilemma is one important step, and a second is to look for policy complementarities that can minimise adverse consequences across the prongs of the trilemma for Indonesia. Where this is not possible, policymakers will have to make some tough choices. For example, micro-hydropower projects that can provide off-grid solutions for those in rural areas are consistent with climate goals, but make very little contribution to meeting the scale of Indonesia's energy demands. The use of coal, at least in the short term, will contribute to Indonesia's energy security, but does not help it to reach its climate change goals and does nothing to relieve the energy poverty of those not on the grid. Working out the available policy complementarities requires, amongst other things, a fine-grain analysis of the country's diverse renewable energy forms, at least some of which could provide viable options for escaping the worst consequences of the trilemma. Examples of these options are discussed in the next section. Although such analysis will almost certainly not reveal a suite of policies that neatly resolve the trilemma, it will help to identify policies that target the trilemma in terms of the appropriate problems that need to be tackled. The degree to which a given policy is able to contribute to the management of the trilemma will become the focal point for evaluating its worth.

\subsection{Sustainability Options and the Trilemma}

As earlier established, Indonesia is rich in a variety of renewable energy resources and has options that offer benefits that fossil fuels do not as an energy source. First, renewable energy is a clean source of energy that gives off low emissions and thus helps to avoid several related costs, including associated health costs (e.g. power plant pollution impacts adversely on neighbouring communities), social costs (e.g. local communities are displaced by extreme weather events or the destruction of forests) and transportation costs (solar and micro-hydropower resources are local while imported coal is not). Interestingly, if similar costs (so-called 'external costs' or 'externalities') associated with power generation from fossil fuels were internalised, the production costs of oil or coal-fired power plants might be higher than that generated from geothermal, wind or solar sources. 
Second, by definition, is the inexhaustibility of renewable energy. As discussed in Sect. 5.2, Indonesia is now facing rapidly diminishing oil reserves; other forms of fossil fuels too will be depleted in the future. This is not the case for the country's renewable resources, which, as at 2011, appear to be abundant. For instance, Indonesia's geothermal energy potential is spread along the islands of Sumatra, Java, Sulawesi and Maluku, which can be explored and developed to partially substitute coal as the main source of energy for power plants. However, only $4.2 \%$ of this potential is currently being used. ${ }^{45}$ When it comes to hydropower, Indonesia has the potential to generate 75,625 MW of power from the source, with $458 \mathrm{MW}$ coming from small-scale hydropower projects (Abdullah 2005, p. 121; UNDP Indonesia 2009, p. 1). As was the case with geothermal energy, only about $6 \%(4.3 \mathrm{GW})$ of Indonesia's total hydropower potential has been utilised (Frost and Sullivan 2011, p. 12). Efforts are underway to develop this resource at various levels. For example, a 2011 Ramon Magsaysay Award recipient, Tri Mumpuni, was recognised for helping her organisation build 60 community-run micro-hydropower plants, with a capacity to generate 5-250 KW of electricity and provide electricity to 500,000 people in rural Indonesia. ${ }^{46}$ The organisation's success gives hope to millions of Indonesians, showing that even complex challenges, such as providing energy to rural Indonesia, can be overcome.

Solar energy radiation too holds out the promise of providing a cheap source of renewable energy and, more importantly, electricity, which might do much to mitigate the conditions of an estimated 70-80 million Indonesians who lack this energy service. Solar photovoltaic (PV) systems have great potential to supply electricity to rural households which are never likely to be reached by a national grid that, on efficiency grounds, must focus on readily accessible and heavily populated areas (Abdullah 2005, p. 123). Solar cookers also have an important role to play in reducing household air pollution.

In the case of biomass, Indonesia has the estimated capacity to provide 146.7 million tons of biomass annually (equivalent to 470 GJ per year), mainly from its significant agricultural and forest areas (Abdullah 2002, p. 1). Most of the biomass energy resources come from rice husk (150 GJ annually), rubber tree trunk (120 GJ annually), cocoa waste (7 GJ annually) and coconut palm waste (67 GJ annually) (Abdullah 2002, p. 3). According to Panaka (2005, p. 3), Indonesia's biomass potential is nearly $49.81 \mathrm{GW}$ while its installed capacity is $445 \mathrm{MW}$. Biomass energy, offers a cleaner energy source, especially for cooking, in contrast to wood and kerosene cookers, which when used indoors account for high levels of ill health and breathing disorders. Wood stoves also provide only $5 \%$ efficiency (Abdullah 2002, p. 3). Biomass can also be used for thermal processes in small-and

45 Alfian, "Indonesia Geothermal Program Hung Up on PLN Pricing Delay", in: The Jakarta Post (22 October 2010), at: http://www.thejakartapost.com/news/2010/10/22/indonesiageothermal-program-hung-pln-pricing-delay.html (16 March 2011).

46 Ardiansyah, Fitrian, "Magsaysay and the Environment", in: The Jakarta Post (7 August 2011), at: http://www.thejakartapost.com/news/2011/08/07/magsaysay-and-environment.html (20 August 2011). 


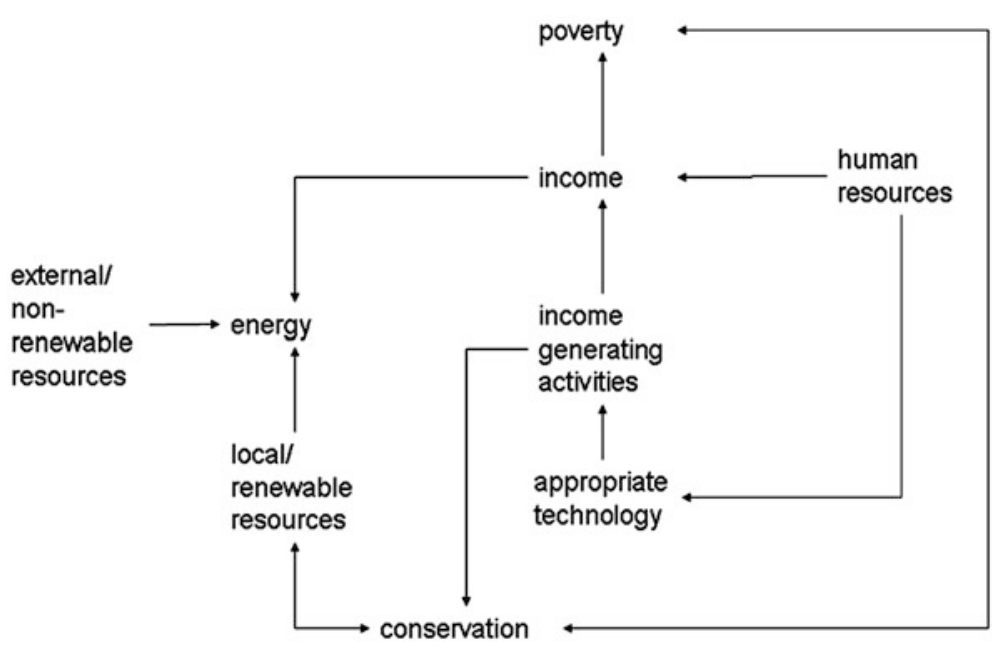

Fig. 5.2 Roles of agro-energy in promoting conservation and poverty alleviation. Source Ardiansyah and Suhud (2007, p. 2)

medium-scale industries, to generate electricity for equipments, such as rice driers, fish or cocoa driers and boilers, or as an energy source for other mechanical tools. It can also be converted to ethanol or biodiesel. Utilising biomass from rural agricultural by-products and waste can not only generate agriculture-based income but also provide increased energy services to rural households (see Fig. 5.2).

Proper utilisation of agro-energy could help prevent encroachment of forests and the uncontrolled collection of firewood and timber for income by large numbers of people by providing them with alternative energy and economic activities. It would also promote higher levels of ownership among local communities of forest areas by pegging forests as the provider of resources that people will likely want to safeguard. A similar logic can be applied to promote microhydropower and, indeed, also be used to persuade the government that the development of sustainable bioenergy can be scaled up through relatively lowscale investment. Tackling energy poverty through micro-projects will enhance the government's leverage when it comes to fuel subsidies reform; current subsidies, as noted earlier, generate long-term energy and fiscal insecurity.

To boost renewable energy development, the central government's general energy policy has advocated the diversification of energy sources and a conversion from coal and petroleum-based fuels to renewable energy sources to reduce emissions. For example, the Government of Indonesia has issued an energy policy (Law No. 30 of 2007), which stipulates that by 2025 the share of renewable energy should be $15 \%$ of the national energy mix. To support this, the Ministry of Energy and Mineral Resources (ESDM) has launched a programme to provide electricity to isolated areas and small islands through, for example, solar PV (with a target of approximately 1,000 solar PV installations by 2008). Similarly, other projects on 
micro-hydropower and other small-scale renewables are also being developed gradually throughout Indonesia. Nonetheless, large-scale renewable energy development needs prioritisation in Indonesia in order to satisfy the significant increase in the country's energy demand, and this calls for the further development of geothermal energy, as it is one of the few renewable energy resources that can compete directly with coal for power generation. Geothermal energy can be used for baseload plant application, with a generation cost that is on par with most fossil fuels. This is reflected well in the second crash programme, outlined earlier, as part of which the government has targeted the private sector to finance and develop nearly $70 \%$ of investments needed for geothermal power (Girianna 2009, p. 1).

Additional measures have also been put in place to allow Indonesia some time while it moves away from its fossil fuel dependence and toward using more renewable energy sources. These measures include energy management, energy saving and the wise use of electricity. The initiative is supported by an internal decree issued by the Indonesian President to government offices to undertake energy-saving steps. With the President's support and the increasing willingness of private sector actors to follow suit, Indonesia's measures to save energy and promote energy efficiency can be expected to contribute significantly to reducing its emissions in the interim.

In the specific context of large-scale bioenergy development with regard to palm oil, a $2007 \mathrm{WWF}$ report suggests that the use of tropical fallow land, especially for planting oil palm is clearly more effective in terms of $\mathrm{CO}_{2}$ savings than clearing of natural forests (Reinhardt et al. 2007, p. 23). Results are not as unequivocal when converting other plantations into oil palm, as it depends on the preceding crop and the substitution effects that flow from its replacement.

Strategic interventions could help to ensure positive GHG deliverance in palm oil development. However, such initiatives dictate that national and local governments adopt a cross-sectoral approach to bioenergy, fostering greater policy coherence among the agriculture, forestry and energy sectors in order to address the risk of conflict between competing land uses and to adopt the most appropriate forms of sustainable energy. This will have to be based on renewable energy supply actions following careful assessment of current and future demand and supply potentials.

A possible concrete and immediate intervention could be reviewing the permit allocation process for oil palm developments. This is an essential step that needs to be undertaken to ensure that these plantations no longer result in deforestation, peatland conversion and degradation. A review of the permits will require strong cross-sectoral coordination. For instance, on 20 May 2011, the Indonesian President signed a presidential instruction (No. 10 of 2011) regarding a two-year moratorium on new permits to clear primary forests and peatlands throughout Indonesia. This long-awaited moratorium, which was intended to reduce deforestation, may provide a venue for pushing not only the overall programme of Reducing Emissions from Deforestation and Forest Degradation Plus (REDD+) but also proper land use management and development in Indonesia. 
Another way to develop oil palm without having to sacrifice forests is by increasing yields of smallholder plantations. In Indonesia, in terms of palm oil yields, smallholders tend to produce only an average of 2.3 tons per ha while private estates can produce up to 3.4 or even 8 tons per ha (Indonesian Forest Climate Alliance 2007, p. 32). Furthermore, the gap between yields on truly wellmanaged and high-yielding private estates and the national average for their group is much larger than it should be. Private producers have recorded 6.5-8.0 tons per ha average yields on individual plantations while the average for the group is little better than 4.1 tons per ha. ${ }^{47}$ Poor smallholder yields are attributed to difficulties in obtaining good quality seedlings, incorrect plantation management and lack of sufficient capital to purchase fertilisers, pesticides and herbicides. If these productivity issues were addressed and improved, there would be no need for the palm oil sector to expand further, as all growth in demand will be met by the improving yields on existing plantations by $1.5-2 \%$ annually (Unilever 2007, p. 1). The intervention will potentially reduce the need to convert forests and peatlands to oil palm. Income increases due to the improving productivity of smallholder plantations will also in turn provide some scope for improving energy services and markets.

In sum, the overall options for sustainability need much more detailed investigation, as no one actor in Indonesia has all the information or evidence needed to effectively manage the trilemma. The crippling effects of the trilemma can only be circumvented through a detailed evidence-based search for policy complementarities involving all parties, be it the government, the industry, civil society or other relevant actors. Nevertheless, a huge opportunity to decouple Indonesia's emissions from its energy development does exist.

\subsection{A Transaction Cost Approach to the Trilemma}

The authors have hitherto argued that Indonesia's energy policy should be conceived within a unifying framework for managing an energy trilemma rather than as a siloed policy process for improving energy security. In this section, the authors propose a general approach for implementing the policies that could contribute positively to managing the trilemma. For example, improving investment in geothermal resources is a plausible policy candidate for managing the trilemma. However, in a world where states have to compete for foreign direct investment and China outcompetes all, there remains the question of how Indonesia may implement a pro-geothermal policy. Our general suggestion here is that Indonesia should look for an approach that will reduce the transaction costs of

47 "Indonesia: Palm Oil Production Growth to Continue", in: USDA (United States Department of Agriculture) (19 March 2009), at: http://www.pecad.fas.usda.gov/highlights/2009/03/ Indonesia/ (16 March 2011). 
implementation. This should not be confused as an argument for deregulation, but should rather be seen as a call for the removal of uncertainties around regulatory decisions already taken and their replacement by efficient executive motors of implementation.

Transaction costs are the costs of searching for, negotiating and enforcing contracts. For the present subject, our focus remains the search and information dimensions of deal-making in the renewable energy sector. Well and truly, before any formal contract is signed, developers in the renewable energy sector have to gather information about the best opportunities and partners available to them. There is an important broader context here. There are many renewable energy investment opportunities available globally to investors as both developed and developing countries, driven by concerns over energy security, begin to set national goals to increase the amount of energy they derive from renewable sources. Korea, for example, has announced, as part of its green growth plan, that it will increase its renewable energy supply from $2.7 \%$ in 2009 to $3.78 \%$ by 2013 and $6.08 \%$ by 2020 (Presidential Commission On Green Growth 2009, p. 13). Similarly, India launched the Jawaharlal Nehru National Solar Mission in 2009 with an aim to provide 22,000 MW of solar power by 2022 (Global Energy Institute 2011, p. 11). There are many more examples that could be cited here. As the global demand for renewable energy initiatives continues, one plausible assumption is that investors will go to those countries where the transaction costs are lower.

Our interviews suggest that external multilateral investment agencies, such as the World Bank, are confronted by an opaque mix of political and multilevel regulatory authorities in Indonesia that generates uncertainty and entails transaction costs for investors. One source of these transaction costs is the division of power between central and local governments. With the current decentralised system, local governments have been given the rights and responsibility to issue concessions and operating licenses for renewable energy. However, most local governments have very limited capacity and understanding of the implications of various energy scenarios and there is no established procedure through which to pursue such initiatives.

Steps that have been taken to improve the quality of energy policy seem to have raised rather than lowered transaction costs. For instance, DNPI, which was established after the Bali Climate Change Conference in 2007, includes 16 cabinet members and involves six working groups of governmental officials to deal with issues of adaptation, mitigation, technology transfer, finance, forestry and postKyoto aims., ${ }^{48,49}$ While DNPI forms a new focal point for climate change strategy, it remains entirely unclear as to what its intended role is with regard to energy

\footnotetext{
48 "National Action Plan: Addressing Climate Change", in: State Ministry of Environment (November 2007), at: http://www.uncsd2012.org/rio20/content/documents/Indonesia\% 20National\%20Action\%20Plan\%20Addressing\%20Climate\%20Change.pdf (16 March 2011).

49 Melisa, Eka, "National Action Plan and International Partnership: Indonesia's Response to Global Efforts to Improve the International Regime on Climate Change", in: National Council on Climate Change (2010), at: http://www.crawford.anu.edu.au/accpforum/pdf/ppp/7_Melisa.pdf (16 March 2011).
} 
governance. Announcements that it will involve "building local capabilities", raise awareness of climate change threats and opportunities and effectively "coordinate Indonesia's response to climate change", are still typically preceded by statements, such as "building the institutional capability to ...", 3 years after DNPI's founding. 50

Even in sectors where one might have expected transaction costs to have been streamlined by virtue of time and regulatory experience, there are problems. For example, Indonesia's oil and gas industry stalled in 2010, with a $25 \%$ fall in state revenue from the sector expected. This was attributed to a failure to realise the sale of a large number of oil and gas blocks. The blame was allocated to erratic local government behaviour, failure of the upstream regulator and the bureaucracy's lack of technical capacity. One Jakarta-based development economist, for instance, described this by saying, "the state bureaucracy has a genius for producing more obstacles or disincentives". 51 This is also reflected in a 2010 survey of Asia's bureaucracies, which rated Indonesia the second worst. ${ }^{52}$

Faced by such transaction cost scenarios, one would expect that investors would react by going instead to China or perhaps Korea. Of course, Indonesia is not the only large developing country that generates high transaction costs for investors through the opaqueness of its political and regulatory system. India is another example. If Indonesia, for instance, were to move to find ways to reduce these transaction costs, then it might provide at least one reason for foreign investors in renewables to prefer Indonesia to India.

In the meantime, the development of renewable resources is moving very slowly. ESDM statistics confirm that, at present, renewable energy (hydropower, geothermal and biomass) accounts for only $3.4 \%$ of total potential reserves. ${ }^{53}$ Large-scale renewable energy development requires large-scale capital investment, and the Indonesian government is looking to the private sector for this investment. However, such investment is not coming in at the scale required at present and this should remain the case if our transaction cost hypothesis is correct. As one senior policymaker, bemoaning the lack of large-scale investment in renewables in Indonesia, said, "we need commitment to invest in a large way".

\footnotetext{
50 "National Council on Climate Change: Low Carbon Development Strategies 03/06/2010", in: Norway (7 July 2010), at: http://www.norway.or.id/Embassy/development/Indonesia/ environment/National-Council-on-Climate-Change-Low-carbon-development-strategies03062010/ (16 March 2011).

51 Lacey, Terry, "Bureaucracy Slows Indonesia Oil and Gas Development", in: Asia Sentinel (12 January 2010), at: http://www.asiasentinel.com/index.php?option=com_content\&task= view\&id=2236\&Itemid=226(16 March 2011).

52 “Indonesia's Bureaucracy among the Worst in Asia: Survey", in: Jakarta Globe (2 June 2010), at: http://www.thejakartaglobe.com/home/indonesias-bureaucracy-among-worst-in-asiasurvey/378341 (16 March 2011).

53 Ardiansyah, Fitrian, "Renewing Support for Renewable Energy", in: The Jakarta Post (2 February 2010), at: http://www.thejakartapost.com/news/2010/02/02/renewing-supportrenewable-energy.html (16 March 2011).
} 
Indonesia can, at least partly, improve its chances of securing this investment commitment if it focuses on governance strategies to reduce transaction costs being generated by layers of its bureaucracy. The use of national councils, such as DNPI and the Dewan Energy Nasional (DEN; also known as National Energy Council), may be useful inter-agency tools for deliberating policy and formulating plans. However, this appears, at least to outsiders, to have added another confusing layer to energy policy development in Indonesia. Understandably, investors would prefer to negotiate with a small stable set of bureaucratic decision-makers having executive powers of implementation instead of a large network of different players. This does not, however, mean that power should be limited to just one department, as extreme centralisation can also create problems of its own. Inter-agency processes involving energy regulators, such as BP Migas (the regulator for gas and oil), and other ministries, such as the Ministry of Finance, are crucially important to energy planning. As the authors have indicated, managing the trilemma will require the participation of many planners and experts from both within and outside the bureaucracy, and no one department should be allowed to direct energy policy - the trilemma is too complex and demanding in terms of information for that to be an efficient solution. Bureaucratic reform to improve planning processes, however, should not compromise the capacity of the bureaucracy to get things done once plans have been formulated, as this is generally a problem in Indonesia. As one interviewee commented, "BAPPENAS sets targets, but how are the targets to get funding? We have to seek support to get the money-either from our internal budget, from donors or from the private sector. And, as regards geothermal, we have to go to the Ministry of Energy to deal with technology and governance. And, the local government has licensing powers and do the transactions with private companies". In short, our suggestion is that Indonesia might look at what it can do to create a stable core of bureaucratic decision-makers who can fill the implementation gaps in Indonesia's energy policy, as processes of authoritative implementation are key to gaining the confidence of investors.

Most interviewees commented upon the rising importance of local governments in Indonesia's energy policy plans. Decision-making has been made immeasurably more complex by the devolution of power in 2003 to the hundreds of districts and municipalities in its 33 provinces, as part of the push for democratisation and regional autonomy following the collapse of Suharto's regime. This devolution has important implications for energy policy, for district governments have been given the right and responsibility to issue not only concessions but also operating licenses for renewable energy and energy efficiency. However, most districts and municipalities have limited capacity and understanding of the various energy scenarios and their implications, and there are no established routes or procedures to pursue such initiatives (IEA 2008, p. 33, 67). Moreover, opportunities for corruption have increased, and indeed corruption is prevalent in many such institutions, because local and regional institutions were unprepared for the transfer of power (Resosudarmo et al. 2000, p. 336).

The central government's macro plans for energy diversification call for close cooperation between district and provincial governments that will inevitably 
continue to think in local rather than national terms. Control over access to land and the various permit systems create opportunities for rent-seeking behaviour of all kinds. Officials at this level of government might also be risk averse when it comes to embracing opportunities for renewable energy projects, as it would be much easier to behave opportunistically and continue working with Indonesian coal companies that, in the words of one interviewee, are "printing money by selling to China". Indeed, the coal industry has had many years of experience in identifying relevant regional government mechanisms and officials through which business might be transacted, and of identifying circumstances and individuals where 'informal' payments may advance negotiations. Solving such problems may not be easy, but they will have to be solved if Indonesia is ever to drop the word 'potential' when it comes to describing its geothermal reserves of energy. Interestingly, all interviewees were acutely aware of the problems facing Indonesia at the local level of government when it came to implementing the strategic vision of its Energy Law of 2007.

Solving these problems will require patience on the part of the central government and negotiation with local governments using whatever financial levers it has at its disposal. One possibility is for the central government to create forums through which multilateral agencies, developers and banks meet with local government officials to explain the scale of funding and investment benefits available to local governments to help make geothermal, or other renewable energy options, a reality for Indonesia. The forum would need to be national in scope, so as to maximise its transparency, and operate under the leadership of the Indonesian President to give it convening power. The basic idea would be to use the forum to trigger a race for renewables, with those who move first at the local government level getting the biggest rewards. Creating such a forum would also help to lower the costs associated with searching for investors. Nationally publicising the success of a local government in, for example, a solar cooker initiative for poor people through the forum would be a good example of the kind of reputational tool that it could potentially be. A forum of 'carrots' could help to stimulate a race among local governments for renewable energy development, especially if driven by the stick of pricing reforms for fossil fuel energy.

\subsection{Conclusion and the Way Forward}

Indonesia's diminishing oil reserves and declining production capacity are putting pressure on the government to immediately come up with a plan to achieve energy security. We have presented that energy security is just one crucial prong of a policy trilemma facing Indonesia, the other two being climate change obligations and energy poverty. Conceiving the problem as managing a trilemma will encourage a more unified approach to its problem solving. The trilemma offers a basic guide to policy-making - its successful management requires a search for policy complementarities that will allow Indonesia to move forward on energy security, energy poverty and climate change. Managing the trilemma requires a fine-grained and 
evidence-based search and assessment of what is possible in the country's renewable energy sector. Policies that address only one prong of the trilemma will probably end up deepening the adverse consequences for the other prongs. For example, continuing with the use of subsidised oil will only cost the country's economy and place Indonesia in competition for a scarce resource, which is hardly a recipe for energy security. Similarly, increasing the use of coal for meeting short-term demand will only create long-term lock-in problems on GHG emissions in addition to promoting the adoption of cheap but inefficient coal technology. Coal, at best, can only serve as a partial response to the severe problems of energy poverty facing Indonesia.

While there is no way to easily resolve the trilemma, there are better ways to manage it. The key, we believe, lies in reforming the bureaucracy using the reduction of transaction costs around the implementation of energy policy as a broad criterion for changes that are essential. Increasing networked governance capacity around energy policy, for instance, via the creation of various councils, such as DNPI and DEN, that serve to enhance the capacity of the Indonesian government to create broader networks around these policies is desirable. What is not desirable is to create confusion and uncertainty around the implementation of energy policy decisions. Decisions once taken should not be allowed to drift into bureaucratic cycles of revisitation and renegotiation that smother investors in a smog of uncertainty. Such a vicious cycle can only favour established industries, such as coal and gas, that know the formal and informal paths to tread in order to achieve their desired outcomes. External investors interested in new initiatives in the renewable energy sector will without doubt end up as losers in this contest, and the upshot will be crash-through energy programmes borne of desperate short-term planning that end up deepening Indonesia's crises. While improving the management of the trilemma is definitely within Indonesia's reach, a necessary prerequisite for such improvement would be bureaucratic reform that targets its organisational practices around the implementation of energy policy.

Acknowledgments The authors would like to thank Muhammad Suhud and Iwan Wibisono for taking up the challenge of preparing and presenting the earliest version of this chapter in 2008 and Desak Putu Adhityani Putri for providing research assistance.

\section{References}

Abdullah K (2002) Biomass energy potentials and utilization in Indonesia. Laboratory of energy and agricultural electrification, Department of Agricultural Engineering, IPB and Indonesian Renewable Energy Society [IRES], Bogor

Abdullah K (2005) Renewable energy conversion and utilization in ASEAN countries. Energy (Amsterdam) 30(2-4):119-128

Agustina CDRD, del Granado JA, Bulman T, Fengler W, Ikhsan M (2008) Black hole or black gold? the impact of oil and gas prices on Indonesia's public finances. Policy research working paper 4718, World Bank, Jakarta

Amir S (2009) Challenging nuclear: antinuclear movements in postauthoritarian Indonesia. East Asian Sci Technol Soc Int J 3(2-3):343-366 
Ardiansyah F, Suhud M (2007) Bioenergy for poverty alleviation. WWF Indonesia, Jakarta

Ariati R (2007) National policy on bioenergy. Paper for the Asian science and technology seminar, Jakarta, Indonesia, 8 March

BAPPENAS (National Development Planning Agency) (2009) Reducing carbon emissions from Indonesia's peat lands. BAPPENAS, Jakarta

Colbran N, Eide A (2008) Biofuel, the environment, and food security: a global problem explored through a case study of Indonesia. Sustain Dev Law Policy 9(1):4-1, 65-67

DNPI (Dewan Nasional Perubahan Iklim) Indonesia (2010) Indonesia's greenhouse gas abatement cost curve. National Council on Climate Change, Jakarta

EPRINC (Energy Policy Research Foundation Incorporated) (2007) Ethanol part II: is a homegrown fuel policy undermining U.S. energy security? EPRINC, Washington, DC

ESDM (Ministry of Energy and Mineral Resources) (2010) Handbook of energy and economic statistics of Indonesia. ESDM, Jakarta

Fredriksson GM, Danielsen LS, Swenson JE (2007) Impacts of el niño related drought and forest fires on sun bear fruit resources in lowland dipterocarp forest of East borneo. Biodiver Conserv 16(6): 1823-1838

Frost \& Sullivan (2011) Global energy mega trends and renewable energy outlook for Indonesia. Media briefing, Jakarta, Indonesia, 30 March

Girianna M (2009) Renewable energy and energy efficiency in Indonesia. Paper for the ADB workshop on climate change and energy, Bangkok, Thailand, 26-27 March

Global Energy Institute (2011) The rising sun-a point of view on the solar energy sector in India. KPMG, India

Hawksworth J (2006) The world in 2050: implications of global growth for carbon emissions and climate change policy. PriceWaterhouseCoopers, London

Hooijer A, Silvius M, Wösten H, Page S (2006) PEAT- $\mathrm{CO}_{2}$ : assessment of $\mathrm{CO}_{2}$ emissions from drained peatlands in SE Asia, Delft Hydraulics Report No. Q3943. Delft Hydraulics, Delft

IEA (International Energy Agency) (2008) Energy policy review of Indonesia. OECD/IEA, Paris

Indonesian Forest Climate Alliance (2007) REDDI: reducing emissions from deforestation and forest degradation in Indonesia: REDD methodology and strategies summary for policy makers. Ministry of Forestry, Jakarta

Koalisi Energi (Koalisi Energi untuk Pembangunan Berkelanjutan) (2005) Tanggapan Koalisi Energi terhadap Blueprint Pengelolaan Energi Nasional (PEN) 2005-2025 dan Usulan Paradigma Baru Pengelolaan Energi Nasional (energy coalition's responses towards the national energy blueprint 2005-2025 and a new proposal on national energy management), Jakarta, Koalisi Energi, WWF Indonesia

Koh LP, Wilcove DS (2008) Is oil palm agriculture really destroying tropical biodiversity? Conserv Lett Hoboken 1(2):60-64

Leitmann $\mathbf{J}$ et al (2009) Investing in a more sustainable indonesia: country environmental analysis, 2009, CEA series East Asia and Pacific region. World Bank, Jakarta

Ministry of Environment (2009) Summary for policy makers: Indonesia second national communication under the United Nations framework convention on climate change (UNFCCC). Ministry of Environment, Jakarta

Ministry of Finance (2009) Ministry of finance green paper: economic and fiscal policy strategies for climate change mitigation in Indonesia. Ministry of Finance, Australia Indonesia Partnership, Jakarta

OECD (Organisation for Economic Co-operation and Development), IEA (International Energy Agency) (2010) Energy poverty: how to make modern energy access universal? OECD/IEA, Paris

Pallone S (2009) Indonesia's oil crisis: how Indonesia became a net oil importer. J Int Policy Solut 10(3): 1-10

Panaka P, (2005) The role of biomass for the energy sustainable development in Indonesia. Paper for the 1st biomass Asia workshop, Hiroshima, Japan, Jan 19-21

Presidential Commission on Green Growth of the Republic of Korea (2009) Road to our future: green growth: national strategy and the five-year plan (2009-2013). Republic of Korea, Seoul 
Reinhardt G, Rettenmaier N, Gärtner S, Pastowski A (2007) Rain forest for biodiesel? Ecological effects of using palm oil as a source of energy. WWF Germany, Frankfurt

Resosudarmo BP, Subiman NIL, Rahayu B (2000) The Indonesian marine resources: an overview of their problems and challenges. Indonesian Q 28(3):336-355

Resosudarmo BP, Alisjahbana A, Nurdianto DA (2010) Energy security in Indonesia, ANU working papers in trade and development No. 2010/08, Australian National University, Canberra

Sa'ad S (2009) An empirical analysis of petroleum demand for Indonesia: an application of the cointegration approach. Energy Policy (Amsterdam) 37(11):4391-4396

Sheil, D, Casson A, Meijaard E, van Noordwijk M, Gaskell J, Sunderland-Groves J, Wertz K, Kanninen M (2009) The impacts and opportunities of oil palm in Southeast Asia: what do we know and what do we need to know? CIFOR occasional paper No. 51, Center for International Forestry Research, Bogor

Teoh CH (2002) The palm oil industry in Malaysia: from seed to frying pan. WWF Switzerland, Zurich

Timilsina GR, Shrestha A (2009) Transport sector $\mathrm{CO}_{2}$ emissions growth in Asia: underlying factors and policy options. Energy Policy Amsterdam 37(11):4523-4539

Tindale S (2009) How to meet the EU's 2020 renewables target, policy brief. Centre for European Reform, London

UNDP (United Nations Development Programme) Indonesia (2009) Project facts: rural development with renewable energy, climate change and sustainable development. UNDP Indonesia, Jakarta

Unilever (2007) Food industry action on palm oil sustainability: Unilever statement. Unilever UK, London

USAID (United States Agency for International Development) (2008) Indonesia energy assessment. USAID, Washington, DC

Wilcove DS, Koh LP (2010) Addressing the threats to biodiversity from oil-palm agriculture. Biodiver Conserv (Dordrecht) 19(4):999-1007

World Bank (2009) Energy and climate change, policy brief 51752. World Bank, Jakarta

\begin{tabular}{|c|c|}
\hline Abbreviation & \\
\hline ADB & Asian Development Bank \\
\hline ANU & Australian National University \\
\hline APEC & Asia-Pacific Economic Cooperation \\
\hline BAPPENAS & $\begin{array}{l}\text { Badan Perencanaan Pembangunan Nasional } \\
\text { (National Development Planning Agency) }\end{array}$ \\
\hline CARR & Centre for the Analysis of Risk and Regulation \\
\hline CIA & Central Intelligence Agency \\
\hline $\mathrm{CO}_{2}$ & Carbon dioxide \\
\hline DEN & Dewan Energy Nasional (National Energy Council) \\
\hline DNPI & $\begin{array}{l}\text { Dewan Nasional Perubahan Iklim Indonesia } \\
\text { (National Council on Climate Change) }\end{array}$ \\
\hline EIA & Energy Information Administration \\
\hline ESDM & $\begin{array}{l}\text { Kementerian Energi dan Sumber daya Mineral } \\
\text { (Ministry of Energy and Mineral Resources, } \\
\text { Republic of Indonesia) }\end{array}$ \\
\hline EU & European Union \\
\hline GDP & Gross domestic product \\
\hline GHG & Greenhouse gas \\
\hline
\end{tabular}




\begin{tabular}{|c|c|}
\hline GJ & Gigajoules \\
\hline GW & Gigawatts \\
\hline GWh & Gigawatts hour \\
\hline ha & Hectares \\
\hline $\mathrm{HCVF}$ & High conservation value forests \\
\hline IAEA & International Atomic Energy Agency \\
\hline IEA & International Energy Agency \\
\hline IFCA & Indonesia Forest Climate Alliance \\
\hline JICA & Japan International Cooperation Agency \\
\hline KW & Kilowatts \\
\hline LNG & Liquefied natural gas \\
\hline LPG & Liquefied petroleum gas \\
\hline mmboe & Millions of barrels of oil equivalent \\
\hline $\mathrm{MtCO}_{2} \mathrm{e}$ & Metric tonnes (tons) of carbon dioxide equivalents \\
\hline mtoe & Million tonnes of oil equivalent \\
\hline MW & Megawatts \\
\hline NAEA & National Atomic Energy Agency \\
\hline OECD & Organisation for Economic Co-operation and Development \\
\hline OHS & Occupational Health and Safety \\
\hline PERTAMINA & $\begin{array}{l}\text { Perusahaan Tambang dan Minyak Negara } \\
\text { (state-owned oil and gas company) }\end{array}$ \\
\hline PLN & Perusahaan Listrik Negara (the state-owned electricity company) \\
\hline PV & Photovoltaic \\
\hline REDD+ & $\begin{array}{l}\text { Reducing Emissions from Deforestation } \\
\text { and Forest Degradation Plus }\end{array}$ \\
\hline REDS & Renewable Energy Development Sector \\
\hline RSPO & Roundtable on Sustainable Palm Oil \\
\hline tbd & Thousand barrels per day \\
\hline tons & Metric tonnes \\
\hline UK & United Kingdom \\
\hline UN & United Nations \\
\hline UNFCCC & United Nations Framework Convention on Climate Change \\
\hline US & United States \\
\hline USAID & United States Agency for International Development \\
\hline USDA & United States Department of Agriculture \\
\hline WWF & World Wide Fund for Nature \\
\hline
\end{tabular}

\section{Author Biographies}

Fitrian Ardiansyah (Indonesia/Australia): He is a climate and sustainability specialist; and former programme director for climate and energy, WWF Indonesia. He has over 15 years of experience in the field of environmental economics, natural resource management, integrated spatial and land use 
planning, sustainable commodities as well as climate change and energy. He is currently finalising his doctoral research at the Crawford School of Economics \& Government, the Australian National University (ANU), Canberra, Australia. Where climate and energy is concerned, he was an expert for the Indonesia Forest Climate Alliance (IFCA), a member of the Indonesian official delegates to the United Nations Framework Convention on Climate Change (UNFCCC) and an advisory board member of the Asian Young Leaders Climate Forum. He was previously adjunct lecturer at the Post Graduate School of Diplomacy, Universitas Paramadina, and a member of the executive board of the Roundtable on Sustainable Palm Oil (RSPO). He recently received the Australian Leadership Award and Allison Sudradjat Award from the Government of Australia. His latest publications include: "Risk and Resilience in Cross-border Areas", in: Elliott, L.; Caballero-Anthony, M. (Eds): Human Security and Climate Change in Southeast Asia (New York: Routledge, forthcoming in February 2012). He also regularly writes for reputable publishers in Southeast Asia.

Neil Gunningham (Australia): He has degrees in law and criminology from the Sheffield University, UK. He is a barrister and solicitor (ACT) and holds a PhD from the Australian National University (ANU). He joined the Regulatory Institutions Network (RegNet) at the ANU in January 2002 and is currently co-director of the National Research Centre for Occupational Health and Safety (OHS) Regulation. He was previously foundation director of the Australian Centre for Environmental Law at ANU, visiting and senior Fulbright scholar at the Center for the Study of Law \& Society, University of California, Berkeley, and visiting fellow at the Centre for the Analysis of Risk and Regulation (CARR), London School of Economics. His work on OHS regulation has focused on the mining industry and on the relationship between management systems-based approaches, trust and workplace culture. The insights generated apply to other industry sectors and resonate for other areas of regulation. One particular concern (as of the Asia-Pacific Economic Cooperation [APEC] Ministers Responsible for Mining) has been OHS in the broader Asia-Pacific region. Other research agendas concern climate change governance-examining how individual states and key actors within them, international institutions, and key non-state actors perceive these challenges as well as their negotiating possibilities and options. Publications include: Mine Safety: Law Regulation Policy (Sydney: Federation Press, 2007); (with Kagan, R.A.; Thornton, D.): Shades of Green: Business, Regulation, and Environment (Stanford: Stanford University Press, 2003); (with Sinclair, D.): Leaders \& Laggards: Next-Generation Environmental Regulation (Sheffield: Greenleaf Publishing Limited, 2002); and (with Grabosky, P.): Smart Regulation: Designing Environmental Regulation (Oxford: Oxford University Press, 1998).

Peter Drahos (Australia): He holds degrees in law, politics and philosophy and is admitted as a barrister and solicitor. He is a professor at RegNet and holds a Chair in Intellectual Property at Queen Mary, University of London. He is a member of the Academy of Social Sciences in Australia. Prior to joining the Australian National University, he was an officer of the Australian Commonwealth Attorney-General's Department, where he drafted Commonwealth legislation. He has published widely in law and social science journals on a variety of topics, including contract, legal philosophy, telecommunications, intellectual property, trade negotiations and international business regulation. He has served as a consultant to the government, international organisations and international non-governmental organisations. Publications include: A Philosophy of Intellectual Property, Applied Legal Philosophy Series (Aldershot-Brookfield, US: Dartmouth Publishing Group, 1996); (with Braithwaite, J.): Global Business Regulation (Cambridge: Cambridge University Press, 2000); (with Braithwaite, J.): Information Feudalism: Who Controls the Knowledge Economy? (London: Earthscan, 2002); (co-edited with Mayne, R.): Global Intellectual Property Rights: Knowledge, Access and Development (Hampshire: Palgrave Macmillan, 2002); and The Global Governance of Knowledge: Patent Offices and Their Clients (Cambridge: Cambridge University Press, 2010). 